\title{
Promoting Social Entrepreneurship among Entrepreneur with Disabilities in Contribution for Community
}

\author{
Norhasyikin Rozali ${ }^{1, *}$, Shuhairimi Abdullah, Jamsari Jamaluddin ${ }^{1}$, Abdul Jalil Ramil ${ }^{1}$, Noor Salwani Hussin ${ }^{1}$ and Aida \\ Zainab Ahmad A $^{2}$ \\ ${ }^{1}$ Malaysia Perlis, Perlis, Malaysia \\ ${ }^{2}$ Institusi Pendidikan Guru Malaysia Kampus Perlis, Perlis, Malaysia
}

\begin{abstract}
Looking forward of the uniqueness social entrepreneurship (SE) new phenomena born from entrepreneurships felid. Because of that it is a new step point for the entrepreneur with disabilities (EWD) to be part of social entrepreneurship environments. Where SE, link the positive impact for society creating by entrepreneur that understand that social problem give a big opportunities for profit or nonprofit activity that can be solve creatively. This give a lot of advantage of EWD to contributes to community in the term of "social impact". This conceptual paper maps SE and EWD in contribution to community with the important role play by stakeholder in promoting SE. This conceptualization enhances understanding of EWD in SE and clear picture of role play by stakeholder give chances for EWD contributes to community.
\end{abstract}

\section{Introduction}

Social entrepreneurship is an exciting new area to explore, but also to provide a very large impact on society. This uniqueness makes social entrepreneurship actively explored by many researchers. According to [7] social entrepreneurship is more effective than commercial entrepreneurship based on ability to added value through creative efforts to solve social problems either non-profit or profitable approach. Scenario unemployment among the disabled people viewed as social issues that still in conversation and multiple solutions has developed to address this issue. There are various obstacles that drive this group inability to get a job. Based on research [15] still these people with disabilities are not getting the job and face a lot of difficulty to enter job markets opportunity. As the government has introduced a proactive step approach to self-employed or are directly involved in entrepreneurship field. This is the step point from the social entrepreneurship will change the landscape of the people with disabilities and at the same time encouraging entrepreneurs with disabilities to participate in society contributed to achieving the social entrepreneurship context.

\section{Promoting Social Entrepreneurship among Entrepreneur with Disabilities}

Social entrepreneurship was born from entrepreneurship. Where entrepreneurship generally, to increase the level of economic growth [12] and also the ability to provide jobs $[8,25,30]$. Entrepreneurship and social entrepreneurship is an area with a significant difference when viewed from the angle of the ability of an entrepreneur to see a social problem that can be handled as a potential business opportunity whether it is profitable or disadvantage $[7,28]$. Opportunity explored by entrepreneurs from various angles, where entrepreneurs are able to optimize the opportunities and resources to gain an advantage through innovation and creativity $[12,29]$.

Social entrepreneurship is a business for social purpose through additional motivation to benefit from the disadvantage, which can create social added value [1, 3]. Social entrepreneurs are able to optimize resources and innovative and creative in finding.

By understanding through the definition of social entrepreneurship and the ability to solve problems where the problem is seen as an opportunities $[9,21,29]$ to ensure that the solutions to social problems can be solved $[11,29]$ as well as add value to society [24]. Social problems or issues are matters related to society and the environment such as poverty, hunger, natural disasters, war, drugs, people with disabilities, youth, women, pollution and so on. Social entrepreneurs will see this problem as an opportunity to complete and able to have a positive impact [13] on society and the environment.

First question will be asked might be, why is social entrepreneurship is innovative approaches used to establish the completion for issue unemployment people with disabled? And how this approach will encourage entrepreneurs with disabilities to contribute to society? Above text show the answers for the first question in general explanation.

\footnotetext{
* Corresponding author: suhairimi@unimap.edu.my
} 
Show that social entrepreneur give big impact to solve social problem in innovative approach [1, 13, 17]. View of the job market that does not guarantee a person with disabilities to get a job and be followed by a variety of obstacles to get the job, and then there is encouragement of stakeholders involved in encouraging people with disabilities to self-employment or entrepreneurship [6]. Among the obstacles are always barriers for people with disabilities to get a job [4, 5, 14, 26] are like discrimination, lack of facilities for people with disabilities as well as employers' perceptions.

Table 1. The Division of Work and the Disabled and Normal

\begin{tabular}{|c|c|c|c|c|c|c|}
\hline \multirow{2}{*}{ Person } & \multicolumn{9}{|c|}{\begin{tabular}{c} 
Percentage \\
\cline { 2 - 7 }
\end{tabular}} & $\begin{array}{c}\text { National Income } \\
\text { Low }\end{array}$ & \multicolumn{2}{c|}{$\begin{array}{c}\text { High-income } \\
\text { Countries }\end{array}$} & \multicolumn{2}{c|}{ All Countries } \\
\cline { 2 - 7 } & Normal & PWD & Normal & PWD & Normal & PWD \\
\hline Male & 71.2 & 58.6 & 53.7 & 36.4 & 64.9 & 52.8 \\
\hline Women & 31.5 & 20.1 & 28.4 & 19.6 & 29.9 & 19.6 \\
\hline $18-49$ & 58.8 & 42.9 & 54.7 & 35.2 & 57.6 & 41.2 \\
\hline $50-59$ & 62.9 & 43.5 & 57.0 & 32.7 & 60.9 & 40.2 \\
\hline $\begin{array}{c}60 \text { and } \\
\text { over }\end{array}$ & 38.1 & 15.1 & 11.2 & 3.9 & 26.8 & 10.4 \\
\hline
\end{tabular}

Sources: World report on disability, 2011

Opportunity to bring in revenue and a positive impact on society. Based on [28] for example, Grameen Bank, founder by Muhammad Yunus, has been successful in implementing micro-credit scheme for poor women out from poverty. Through social entrepreneurship approach has been successfully implemented to help solve the problem of poverty.

Therefore, it is important remedy identify the essence of social entrepreneurship is important in order to make social issues to social fortune to society. Recently, the government has undertaken various initiatives in order to help people with disabilities to overcome barriers to employment such as establish policies and laws encourage joining the government or the private sector [5] [15]. At the same time provide education and training program and activities to encourage the disabled to work or engage in entrepreneurship [6].

The government is still not achieving the desired goals of these groups. Based on study done by [29] show that increased interest in social entrepreneurship potential remedy makes the problem more innovative. To promote social entrepreneurship exposure to entrepreneur with disabilities should be ongoing in order effects or results to society can be maintained not only temporary. According to [23] entrepreneur play important role as a second invisible hand responsible to society by giving innovative solutions for social problem. The role of stakeholders is very important $[10$, 22] in provide a facility for developing entrepreneurship through social entrepreneurs need to ensure that people with disabilities are not left behind and social goals can be achieved.

The role played by the government [6] in helping to promote and give exposure to the entrepreneur with disabilities is important to sees such a great potential to add value not only to their own group of disabled peoples but also to the community. Through the involvement of the government in promoting social entrepreneurship, other approaches through education and training and under the supervision of program [20, 31] can help to encourage disabled entrepreneurs directly involved.

Response for social problem facing by many country roles play by government is one of important key to provide a solution for social problem. Because of that, an innovative approach by collaboration between government and social entrepreneur will leverage public and private resources and generate transformative and cost-effective solutions to the most challenging social problems facing in the country itself [27]. Based on the Report to the President, 2007, by The Small Business Administration, Office of Advocacy suggest few methods that can be used by government agencies and elected officials to (1) encourage social entrepreneurs to innovate, (2) create enabling environments for their efforts, (3) reward their performance, (4) help scale their successes, and (5) produce knowledge to help them solve social problems[27].

According to [16], also agree that government support for social entrepreneurship as an approach for strengthening communities by social entrepreneur involves private individuals and organizations taking the initiative to address social challenges in their communities.

\section{Entrepreneur with Disabilities Contribution to Community in Context of Social Entrepreneurship}

Through the encouragement of people with disabilities to engage in entrepreneurial viewed indirect impact on employment opportunities encourage the fate and overcome unemployment [17] [22] and poverty of these people. Table 1 show high of differences between incomes earned from normal people and people with disabilities this is evidence that many of people with disabilities still in poverty because of incomes they earned. Entrepreneur with disabilities will become agents of intermediate action to ensure that people with disabilities are not left out in the same boat, and even contribute back to society [24] in the context of larger social entrepreneurship impact.

The first step is to change a disabled to successful entrepreneurs with disabilities and at the same time makes successful social entrepreneurs with disabilities who can contribute to society, where previous years people with disabilities who are subject to the social mission of the business is not yet come into force [22].

Social entrepreneurship good platform for people with disabilities that will trigger a new world in entrepreneurship or social entrepreneurship. No issue, to question of the ability of entrepreneurs with disabilities if viewed from the angle of equal opportunity which is always highlighted [5, 20, 15] [31]. In addition, the 
power to motivate and encourage entrepreneurs trials that the disabled have become a powerful starting point to them to put themselves in entrepreneurship [20] should receive due recognition and more opportunities are highlighted.

Social impact that will have a direct impact on disabled people will indirectly resolve an issue faced by disabled people and entrepreneurs can contribute to society. References [23] entrepreneur drive the economy by efficient outcomes trues the systematic identifying social problem with positive externalities and develops approach into economic system. Contribution of entrepreneur are not much differences, entrepreneur also frequently act to social manner but for social entrepreneur they always look for social problem directly in mission social solving add creating social impact [9].

Involvement of entrepreneurs with disabilities in social entrepreneurship will produce social entrepreneurs who will contribute to society through a variety of approaches and channels. Maybe in terms of education or charity or charitable contributions can help people then indirectly add value to society. Contribute to the disabled will be translated more clearly based on previous experience, based on the role played by social entrepreneurs are able to provide more employment opportunities[6, 20, 21], providing better facilities, and education and training directly with more effectively.

\section{Summary}

This paper provides a conceptual map in social entrepreneurship approach is explained in general about entrepreneurs with disabilities and the role it played by the government to help raise awareness among entrepreneurs about social entrepreneurship. Therefore, it is important to ensure the lack of exploration of entrepreneurship in the context of social entrepreneurship so that they are no longer stuck in unemployment problems or poverty for people with disabilities. At the same time entrepreneurs with disabilities will have the opportunity to contribute to society. In the end of social entrepreneur community will gain the benefit from creative and innovative approach of social entrepreneur.

\section{Future Agenda}

In future agenda, researchers hope to explore more about experiences face by successful entrepreneurs with disability and build a modal based on social entrepreneur's perspectives for entrepreneur with disabilities. In addition, to explore more in how they can involve with social entrepreneur and at the same time contribute to society.

\section{References}

1. S. Abu Saifan, Social entrepreneurship: definition and boundaries. TechnologyInnovation Management Review, (February), 22-27. Retrieved from: http://www.timreview.ca/article/523

2. J. A. Ahmad, U. T. Mara, Social Enterpreneurship in Ecotourism: An Opportunity for Fishing Village of Sebuyau, Sarawak Borneo. Tourism, Leisure and Global Change, 1(April 2013), 22-24 (2014)

3. S.H. Alvord, L.D. Brown, C.W. Letts, Social Enterpreneurship and Social Transformation - An Exploratory Study (2002)

4. Ang, M. (2012). Work and Disability: A Malaysian Scenario. Penerbit Universiti Sains Malaysia.

5. M.C. Ang, Jurnal Pengurusan 41, 81-89 (2014)

6. W.A.W. Arnidawati, ECONOMY REPORT APEC FORUM ON HUMAN RESOURCES DEVELEPMENT 2013, Human Resources Development for People with Disabilities “Improvement Employability. "(2013)

7. J. Austin, H. Stevenson, J. Wei-Skillern, Social and commercial entrepreneurship: Same, different, or both? Entrepreneurship: Theory and Practice 30(1), 1-22 (2006) http://doi.org/10.1111/j.15406520.2006.00107.x

8. P.D. Blanck, L.A. Slander, J.L. Schmeling, H.A. Schartz, The Emerging workforce of entrepreneurs with Disabilities: Preliminary Study of Entreprenuership in Iowa (2002)

9. B.J. Boschee, J. Mcclurg, J. (2003). Toward a better understanding of social entrepreneurship: Some important distinctions. Chief Executive, 1-5. Retrieved from http://www.sealliance.org/better_understanding.pdf

10. K. Caldwell, S.P. Harris, M. Renko, Intellectual and Developmental Disabilities, 50(6), 505-518 (2012).

11. S.T. Certo, T. Miller, Social entrepreneurship: Key issues and concepts. Business Horizons, 51(4),267271(2008)

12. T. Cooney, T. Irish Business Journal, 4(1), 119-129 (2008)

13. J.G. Dees, Transaction Social Science and Modern, 44(3), 145 (2007)

14. S.L. Khoo, T.L. Ta,L.W. Lee, International Jouranl of Sosial, Education, Economics and Management Engeneering, 6(6), 255-260 (2012)

15. S.L. Khoo, L. Tiun, L.W. Lee, Kajian Malaysia, 31(1), (2013)

16. M.L. Korosec, M. L., \& Berman, E. M. (2006). Municipal support for social entrepreneurship. Public Administration Review, 66(3), 448-462.

17. J. Mair, I. Martí, Journal of World Business, 41(1),36-44 (2006)

18. J. Mair, J. Robinson, K. Hockerts, Social Entrepreneurship. PALGRAVE MACMILLAN 32 (2006) http://doi.org/10.1057/9780230625655

19. P.J. Murphy, S.M. Coombes, Journal of Business Ethics, 87(3), 325-336 http://doi.org/10.1007/s10551-008-9921-y

20. O. Norasmah, Keusahawanan Orang Kurang Upaya Di Malaysia. (Dewan Bahasa Dan Pustaka, 2014) 
21. Osman, Che Asniza, H. Rahim, Journal of Basic and Applied Sciences, 8(23), 62-69 (2014)

22. S. Parker Harris, M. Renko, K. Caldwell, Disability \& Society, 29(8), 1275-1290 (2014) http://doi.org/10.1080/09687599.2014.924904

23. F.M. Santos, F. M. Journal of Business Ethics, 111(3), 335-351 (2012) http://doi.org/10.1007/s10551-012-1413-4

24. C. Seelos, J. Mair, Business Horizons, 48(3), 241246 http://doi.org/10.1016/j.bushor.2004.11.006

25. G. Shaheen, W.N. Myhill, Entrepreneurship for Veterans with Disabilities : Lessons Learned from the Field Factors Affecting Employment Among Veterans with Disabilities Entrepreneurship as a Viable Career Option for Veterans with Disabilities Meeting the Needs of Future Veteran Bu. Brief, (1), 1-8 (2009)

26. T.L. Ta, K.S. Leng, Challenges Faced by Malaysians with Disabilities in the World of Employment. Disability, CBR \& Inclusive Development, 24(1), (2013) http://doi.org/10.5463/dcid.v24i1.142

27. M.A. Wolk, Social Entrepreneurship \& Government (2007)

28. M. Yunus, B. Moingeon, L. Lehmann-Ortega, Long Range Planning, 43(2-3), 308-325 (2010). http://doi.org/10.1016/j.lrp.2009.12.005

29. S. Zahra, H. Rowhouser, N. Bhawe, D. Neubaum, J. Hayton, Strategic Entrepreneurship Journal, 2(2), 117-131 (2008) http://doi.org/10.1002/sej.43

30. A. Zalinawati, M. Norudin, The Relationship between Environmental Factors and Opportunities to became entrepreneur among visually Impaired (2007)

31. A. Zinaida, Kerjaya untuk Orang Kurang Upaya (PTS Professional, Publishing Shd.Bhd., 2006) 